\title{
Flow resistance in the engine inlet-exhaust system as affected by the engine parameters
}

\begin{abstract}
The paper presents theoretical and experimanetal research into the process of charge exchange in a spark ignition engine (the process of cylinder filling and discharging). A significant role in the inlet system plays the resistance of the flow of a fresh charge through the throttle, particularly when its partially opened. In classic spark ignition engine solutions this flow resistance is a part of the engine load imposition. The problem has been illustrated by the theoretical and experimental test results of the influence of the pressure drop $\Delta p_{d}$ on the side of the fresh charge flow and the pressure drop $\Delta p_{w}$ in the exhaust system on the engine operation. Relations have been determined between the engine operating parameters and the flow conditions of the chargelexhaust gases.
\end{abstract}

Key words: combustion engine, inlet system, exhaust system, flow resistance, pressure drop, charge exchange work

\section{Ksztaltowanie się oporów przepływu w układzie wymiany ladunku na tle parametrów pracy silnika spalinowego}

\begin{abstract}
$W$ artykule przedstawion teoretyczne i eksperymentalne badania ogólnego procesu wymiany ładunku silnika spalinowego o zapłonie iskrowym, $w$ którym uwzględnia się zarówno proces napetniania, jak $i$ wyplyw spalin. Istotna rolę $w$ układzie dolotowym odgrywa opór przepływu świeżego ładunku przez przepustnicę, szczególnie w sytuacji częściowego jej otwarcia. W typowych rozwiąaniach silników o zapłonie iskrowym opór ten spetnia rolę elementu regulacji obciązenia. Problematykę zilustrowano wynikami badań, teoretycznych i eksperymentalnych, wpływu spadku ciśnienia $\Delta p_{d}$ po stronie dopływu świeżego tadunku do silnika oraz spadku ciśnienia $\Delta p_{w}$ spalin w uktadzie wylotowym, na pracę silnika ZI. Określono wzajemne zależności pomiędzy eksploatacyjnymi parametrami pracy silnika a warunkami przepływu świeżego tadunku i spalin.

Słowa kluczowe: silnik spalinowy, układ dolotowy, układy wylotowy, opory przepływu, spadek ciśnienia, praca wymiany tadunku
\end{abstract}

\section{Introduction - the process of charge exchange}

The charge exchange depends on the cyclicity of the combustion engine operation. This process encompasses:

- cylinder filling with a fresh charge (air or combustible mixture)

- discharging of the combustion products.

The process of charge exchange is realized through the following systems: inlet and exhaust.

Tasks of the inlet system:

- supply of fresh charge and preparation of the combustible mixture

- the aspects of load control (air excess ratio $\lambda$, volumetric efficiency $\eta_{v}$, fuel dose $m_{p}$ ).

Tasks of the exhaust system:

- controlled exhaust discharge

- ecological and energy related aspects within the aftertreatment measures.

Mutual interactions of the phenomena occurring in the inlet and exhaust systems and the cylinder are observed. There are direct and indirect interactions - the exhaust temperature influences the temperature level of the whole exhaust system and the temperature level affects the efficiency of the catalytic converter.

\section{Wprowadzenie - znaczenie procesu wymiany ladunku}

Wymiana ładunku uwarunkowana jest cyklicznością pracy silnika spalinowego. Na proces ten składa się:

- napełnianie cylindrów świeżym ładunkiem (powietrzem lub mieszanką palną)

- odprowadzenie produktów spalania.

Proces wymiany ładunku realizowany jest poprzez układy: dolotowy i wylotowy, które spełniają swoje indywidualne zadania:

uklad dolotowy:

- doprowadzenie świeżego ładunku oraz przygotowanie mieszanki palnej

- aspekty sterowania i regulacji (stosunek nadmiaru powietrza $\lambda$, stopień napełnienia $\eta_{v}$, dawka paliwa $\mathrm{m}_{\mathrm{p}}$ ), uklad wylotowy:

- kontrolowane wyprowadzanie spalin do otoczenia

- aspekty energetyczno-ekologiczne w ramach tzw. przedsięwzięć wtórnych.

Zauważa się wzajemne oddziaływanie zjawisk zachodzących w układach dolotowym i wylotowym oraz procesów w cylindrze. Można wskazać na oddziaływanie pośrednie i bezpośrednie; np. temperatura spalin opuszczających cylinder wpływa na poziom nagrzania całego układu 
The influence of the charge exchange system on the engine work efficiency is significant. The individual elements fitted in the charge exchange system generate flow resistance of the fresh charge in the inlet system and the outflow of the gases in the exhaust system (Fig. 1). The result of such a resistance is the increase in the work of the charge exchange, which in turn adds to the reduction of the internal work of the engine and its efficiency.

The process of charge exchange is tightly related to the way of generating the engine load. Two systems of load control are applied [1]:

quantitative - applied in spark ignition engines (SI); in this system the basic power control element is the flow resistance of the charge in the inlet system set by a given throttle position, qualitative - applied in the diesel engines (CI), whose principle is the wide variability of air excess ratio $\lambda$.

Characteristic features of the quantitative load control [1]: - adjusting of the mass of the medium (the sum of the mass of the supplied air and the fuel dose) to a current power demand, which usually results in a given pressure $\mathrm{p}_{1}$ in the cylinder after its filling

- the state of the required adjustment of the medium mass is most frequently achieved through an appropriate position of the throttle (choking) in the inlet channel

- during the flow of the gas through the throttle an intense fluid choking occurs (isenthalpic), which, as an irreversible process, generates losses of exergy (increase of the charge exchange work) in the cylinder filling process [2]

- the excess of oxygen (air) $\lambda$ and the stoichiometric content of the mixture prepared for the combustion remain on an almost unchanged level, irrespective of the engine load.

\section{The work of the reference engine cycle including the work of the charge exchange}

A theoretical, qualitative and quantitative analysis of the influence of the flow resistance $\Delta p_{d}$ of the fresh charge through the inlet system and the flow resistance $\Delta \mathrm{p}_{\mathrm{w}}$ of the gases in the exhaust system on the engine operation has been performed assuming the Seiliger-Sabathe reference cycle as a model of the processes occurring in spark ignition engines (Fig. 2).

For the Seiliger-Sabathe cycle characteristic parameters have been defined [1]:

- compression ratio

$$
\varepsilon=\frac{V_{1}}{V_{2}}
$$

wylotowego, a przez poziom temperatury na skuteczność działania reaktora katalitycznego.

Istotny jest wpływ układu wymiany ładunku na efektywność pracy w silniku. Poszczególne elementy instalowane w układzie wymiany ładunku wywołują opory przepływu świeżego ładunku w układzie dolotowym i przepływu spalin w układzie wylotowym (rys. 1). Skutkiem tych oporów jest wzrost pracy wymiany ładunku, co z kolei przyczynia się do obniżenia pracy wewnętrznej i efektywnej silnika spalinowego.

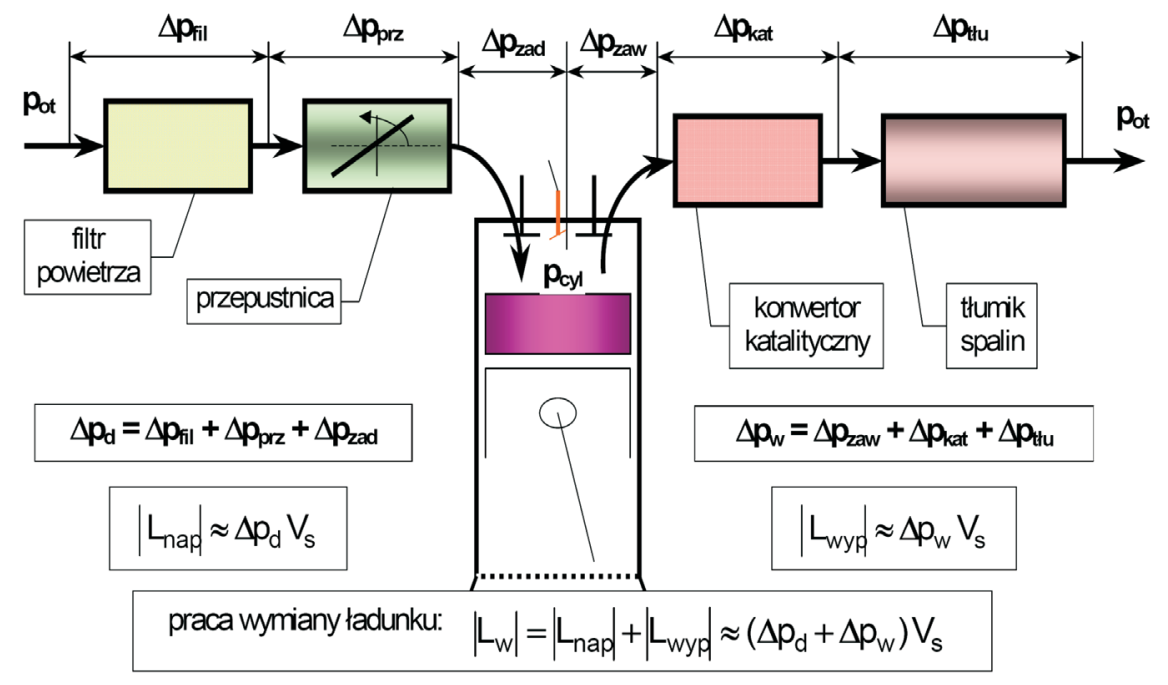

Fig. 1. The basic elements of the charge exchange in a spark ignition engine Rys. 1. Zasadnicze elementy układu wymiany ładunku silnika o zapłonie iskrowym

Proces wymiany ładunku jest ściśle związany ze sposobem regulacji obciążenia silnika spalinowego. Stosowane są dwa systemy regulacji [1]:

ilościowa - stosowana $\mathrm{w}$ silnikach $\mathrm{z}$ zapłonem iskrowym (ZI); w tym systemie podstawowym elementem regulacji mocy jest opór przepływu ładunku w układzie dolotowym, ustalany przez odpowiednie ustawienie przepustnicy,

jakościowa - stosowana w silnikach z zapłonem samoczynnym (ZS), której istotną cechą regulacyjną obciążenia jest szeroki zakres zmian nadmiaru powietrza $\lambda$.

Charakterystyczne cechy ilościowej regulacji obciążenia silnika [1]:

- dopasowanie masy czynnika roboczego (suma masy doprowadzonego powietrza oraz masy dawki paliwa) do aktualnego zapotrzebowania mocy, co skutkuje zazwyczaj odpowiednim poziomem ciśnienia $\mathrm{p}_{1} \mathrm{w}$ cylindrze po jego napełnieniu

- stan wymaganego dopasowania masy czynnika roboczego osiąga się najczęściej przez odpowiednie ustawienie przepustnicy (dławienie) na kanale dopływowym

- podczas przepływu gazu przez przepustnicę występuje intensywne dławienie płynu (izentalpowe), które jako przemiana zawsze nieodwracalna generuje straty egzergii (wzrost wykonanej pracy wymiany ładunku) w procesie napełniania silnika [2] 
- load parameter $(\mathrm{V}=\mathrm{idem})$

$$
\gamma=\frac{\mathrm{p}_{3}}{\mathrm{p}_{2}}
$$

- second load parameter $(\mathrm{p}=$ idem $)$

$$
\varphi=\frac{V_{4}}{V_{3}}
$$

- heat distribution number

$$
\Psi=\frac{\mathrm{Q}_{\mathrm{d}, \mathrm{v}}}{\mathrm{Q}_{\mathrm{d}}}
$$

-energy-stoichiometric parameter [1]

$$
\mathrm{E}=\frac{\mathrm{Q}_{\mathrm{d}}}{\mathrm{p}_{1} \mathrm{~V}_{1}}
$$

The above defined parameters have been shown in Fig. 2.

The work of the charge exchange is impactful on the value of the work of the cycle. The considerations shall relate to the case of charge exchange for which the filling process is included as expressed in:

$$
\left(\frac{\Delta \mathrm{p}_{\mathrm{d}}}{\mathrm{p}_{0}}\right)>0
$$

and the exhaust of the gases is included i.e. when the condition:

$$
\left(\frac{\Delta \mathrm{p}_{\mathrm{w}}}{\mathrm{p}_{0}}\right)>0
$$

is fulfilled

where: $\Delta p_{d}-$ average pressure drop on the cylinder inlet side, $\Delta p_{w}$ - average pressure drop on the cylinder exhaust side, $\mathrm{p}_{0}-$ ambient pressure.

The value of work $\mathrm{L}_{\mathrm{w}}$ of the charge exchange for a single cycle is:

but

$$
\mathrm{L}_{\mathrm{w}}=\mathrm{L}_{\text {nap }}+\mathrm{L}_{\text {wyp }}, \mathrm{L}_{\text {nap }}>0, \quad \mathrm{~L}_{\text {wyp }}<0
$$

$$
\left|\mathrm{L}_{\text {wyp }}\right|>\mathrm{L}_{\text {nap }} \Rightarrow \mathrm{L}_{\mathrm{w}}<0
$$

where: $\mathrm{L}_{\text {nap }}-$ work of the cylinder filling with a fresh charge, $\mathrm{L}_{\text {wyp }}$ - work related to the evacuation of the exhaust gases.

The value of work $\mathrm{L}_{\mathrm{w}}$ of the charge exchange can be estimated as:

$$
\left|\mathrm{L}_{\mathrm{w}}\right| \approx\left(\Delta \mathrm{p}_{\mathrm{d}}+\Delta \mathrm{p}_{\mathrm{w}}\right) \mathrm{V}_{\mathrm{s}}
$$

where: $\mathrm{V}_{\mathrm{s}}$ - cylinder capacity.

When determining of the work of the cycle $\mathrm{L}_{\mathrm{o}}$ including the work $\mathrm{L}_{\mathrm{w}}$ of the charge exchange, we should not only include the work of the charge exchange itself but also the fact of the initial pressure drop $p_{1}$ of the cycle by $\Delta p_{d}$ during the cylinder filling:

$$
\mathrm{p}_{1}=\mathrm{p}_{0}-\Delta \mathrm{p}_{\mathrm{d}}
$$

and the increase in the final pressure $\mathrm{p}_{6}$ by $\Delta \mathrm{p}_{\mathrm{w}}$ during the evacuation of the exhaust gases:
- nadmiar tlenu (powietrza) $\lambda$ oraz skład stechiometryczny mieszanki palnej przygotowanej do procesu spalania pozostają prawie na niezmienionym poziomie, niezależnie od samego obciążenia silnika.

\section{Praca porównawczego obiegu silnika spalinowego $\mathrm{z}$ uwzględnieniem pracy wymiany ladunku}

Teoretyczną, jakościową i ilościową analizę wpływu oporów $\Delta \mathrm{p}_{\mathrm{d}}$ przepływu świeżego ładunku przez układ dolotowy oraz oporów $\Delta \mathrm{p}_{\mathrm{w}}$ wypływu spalin w układzie wylotowym na pracę silnika przeprowadzono, przyjmując obieg porównawczy Seiligera-Sabathe'a, jako model procesów zachodzących w silniku spalinowym o zapłonie iskrowym (rys. 2).

Dla obiegu Seiligera-Sabathe'a zdefiniowano charakterystyczne parametry [1]:

- stopień kompresji - wzór (1)

- parametr (stopień) obciążenia (V = idem) - wzór (2)

- parametr (stopień) dociążenia $(\mathrm{p}=\mathrm{idem})$ - wzór (3)

- liczba rozdziału ciepła (4)

- parametr energetyczno-stechiometryczny [1] - wzór (5), gdzie parametry występujące $\mathrm{w}$ powyższych definicjach zaznaczono na rys. 2.

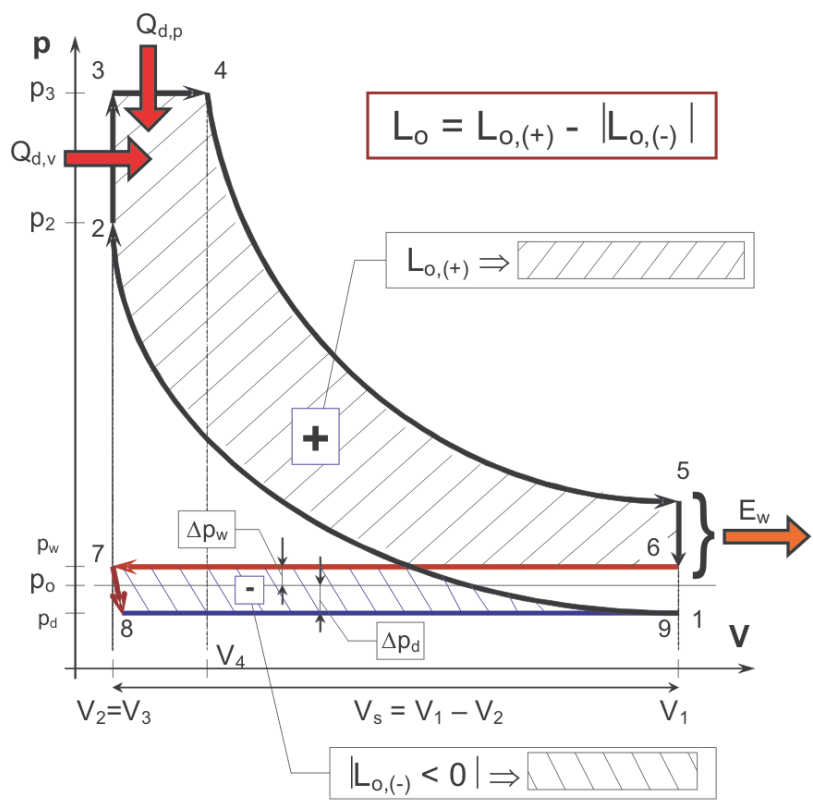

Fig. 2. Reference Seiliger-Sabathe cycle including the resistance and the work of the charge exchange

Rys. 2. Obieg porównawczy Seiligera-Sabathe'a z uwzględnieniem oporów i pracy wymiany ladunku

$\mathrm{Na}$ wartość wyznaczanej pracy obiegu istotny wpływ ma praca wymiany ładunku. Rozważania dotyczyć będą przypadku wymiany ładunku, w którym uwzględnia się zarówno proces napełniania silnika, co można wyrazić warunkiem (6), jak również proces wypływu spalin, czyli przy spełnieniu warunku (7),

gdzie: $\Delta \mathrm{p}_{\mathrm{d}}-$ średni spadek ciśnienie po stronie dopływowej do cylindra, $\Delta \mathrm{p}_{\mathrm{w}}$ - średni spadek ciśnienie po stronie wypływowej z cylindra, $\mathrm{p}_{0}$ - ciśnienie normalne (otoczenia). 


$$
\mathrm{p}_{6}=\mathrm{p}_{0}+\Delta \mathrm{p}_{\mathrm{w}}
$$

In such an approach the work of cycle $\mathrm{L}_{\mathrm{o}}$ can be determined as $[1,3]$ :

$$
\mathrm{L}_{\mathrm{o}}=\oint_{\mathrm{ob}} \mathrm{pdV}
$$

The integral (13) can be noted as a sum of absolute works $\mathrm{L}_{\mathrm{i}}$ of individual processes forming the cycle:

$$
\begin{aligned}
\mathrm{L}_{\mathrm{o}}= & -\left|\mathrm{L}_{1-2}\right|+\mathrm{L}_{2-3}+\mathrm{L}_{3-4}+\mathrm{L}_{4-5}+ \\
& +\mathrm{L}_{5-6}-\left|\mathrm{L}_{6-7}\right|+\mathrm{L}_{7-8}+\mathrm{L}_{8-9}
\end{aligned}
$$

After determining of the composites of the absolute works and summing them up according to formula (14) the work $\mathrm{L}_{\mathrm{o}}$ of the cycle is expressed in the relation:

$$
\mathrm{L}_{\mathrm{o}}=\mathrm{p}_{0} \mathrm{~V}_{1}\left\{\mathrm{~F}_{\mathrm{L}}-\left(\frac{\Delta \mathrm{p}_{\mathrm{d}}}{\mathrm{p}_{0}}\right)\left[\mathrm{F}_{\mathrm{L}}+\frac{\varepsilon-1}{\varepsilon}\right]-\frac{\varepsilon-1}{\varepsilon}\left(\frac{\Delta \mathrm{p}_{\mathrm{w}}}{\mathrm{p}_{0}}\right)\right\}
$$

where the auxiliary function is

$$
\mathrm{F}_{\mathrm{L}}(\varepsilon, \gamma, \varphi)=\frac{\varepsilon^{(\kappa-1)}[(\gamma-1)+\kappa \gamma(\varphi-1)]-\left(\gamma \varphi^{\kappa}-1\right)}{\kappa-1}
$$

It is easier to conduct the analysis of the work of the cycle in a relative system (dimensionless) with reference to an ideal cycle. The ideal cycle is characterized by a lack of flow resistance in the inlet and exhaust system:

$$
\Delta \mathrm{p}_{\mathrm{d}}=0 \quad \text { oraz } \quad \Delta \mathrm{p}_{\mathrm{w}}=0
$$

hence the charge exchange work is also zero: $\mathrm{L}_{\mathrm{w}}=0$. The work $\mathrm{L}_{0,0}$ of the ideal cycle could be expressed with a dependence:

$$
\mathrm{L}_{\mathrm{o}, 0}=\left(\mathrm{p}_{0} \mathrm{~V}_{1}\right) \mathrm{F}_{\mathrm{L}}(\varepsilon, \gamma, \varphi)
$$

The quotient (15)/(18) enables the determining of the relative work of the cycle:

$$
\left(\frac{\mathrm{L}_{o}}{\mathrm{~L}_{\mathrm{o}, 0}}\right)=1-\left\{\begin{array}{l}
\left(\frac{\Delta \mathrm{p}_{\mathrm{d}}}{\mathrm{p}_{0}}\right)\left[1+\frac{\varepsilon-1}{\varepsilon \mathrm{F}_{\mathrm{L}}(\varepsilon, \gamma, \varphi)}\right]+ \\
+\left(\frac{\Delta \mathrm{p}_{\mathrm{w}}}{\mathrm{p}_{0}}\right) \frac{\varepsilon-1}{\varepsilon \mathrm{F}_{\mathrm{L}}(\varepsilon, \gamma, \varphi)}
\end{array}\right\}
$$

A graphic image of function (19) of the relative work of the Seiliger-Sabathe cycle is the surface shown in Fig. 3. The shape of the function under analysis shows that the drop in pressure $\Delta p_{d}$ on the inlet side while filling the cylinder with a fresh charge much more significantly influences the work of the cycle than resistance $\Delta \mathrm{p}_{\mathrm{w}}$ of the gas flow in the exhaust system.

The relative work of the reference cycle has been shown in Fig. 3 in a wide range of flow resistance variations. That is why the characteristic work point of the ideal cycle has been marked in the figure:

$-\mathbf{L}_{\mathbf{o}, 0}-$ work point of the ideal cycle for $\Delta \mathrm{p}_{\mathrm{d}}=0$ and $\Delta \mathrm{p}_{\mathrm{w}}=0$,
Wielkość pracy $\mathrm{L}_{\mathrm{w}}$ wymiany ładunku dla jednego cyklu wynosi (8), ale $\mathrm{L}_{\text {wyp }}$ pokazuje wzór (9),

gdzie: $\mathrm{L}_{\text {nap }}$ - praca napełniania cylindra świeżym ładunkiem, $\mathrm{L}_{\text {wyp }}$ - praca związana $\mathrm{z}$ wypływem spalin $\mathrm{z}$ cylindra silnika.

Wartość pracy $\mathrm{L}_{\mathrm{w}}$ wymiany ładunku można oszacować jako (10),

gdzie: $\mathrm{V}_{\mathrm{s}}$ - objętość skokowa cylindra.

Wyznaczając wielkość pracy obiegu $\mathrm{L}_{\mathrm{o}}$, przy uwzględnieniu pracy $\mathrm{L}_{\mathrm{w}}$ wymiany ładunku, należy uwzględnić nie tylko wartość samej pracy wymiany ładunku, ale także obniżenie ciśnienia początkowego $\mathrm{p}_{1}$ obiegu o wartość $\Delta \mathrm{p}_{\mathrm{d}}$ podczas napełniania cylindra (11) oraz podwyższenie ciśnienia końcowego $\mathrm{p}_{6}$ o wartość $\Delta \mathrm{p}_{\mathrm{w}} \mathrm{w}$ czasie wypływu spalin (12).

$\mathrm{W}$ takim ujęciu pracę obiegu $\mathrm{L}_{\mathrm{o}}$ można wyznaczyć jako całkę (13) [1,3]. Całkę (13) można zapisać jako sumę prac bezwzględnych $\mathrm{L}_{\mathrm{i}}$ poszczególnych przemian tworzących obieg (14).

Po wyznaczeniu składowych prac bezwzględnych i zsumowaniu ich zgodnie ze wzorem (14), praca $\mathrm{L}_{\mathrm{o}}$ obiegu wyraża się zależnością (15), gdzie pomocniczą funkcję wyraża (16).

Dogodniej jest prowadzić analizę pracy obiegu w układzie względnym (bezwymiarowym), w odniesieniu do obiegu idealnego. Obieg idealny charakteryzuje się brakiem oporów przepływu w układzie dolotowym i wylotowym (17), skąd wynika, że praca wymiany ładunku także wynosi zero: $\mathrm{L}_{\mathrm{w}}=0$. Natomiast praca $\mathrm{L}_{\mathrm{o}, 0}$ obiegu idealnego wyrażona może być zależnością (18).

Iloraz równań (15) i (18) umożliwia wyznaczenie względnej pracy obiegu (19).

Graficznym obrazem funkcji (19) względnej pracy obiegu Seiligera-Sabathe'a jest powierzchnia przedstawiona na rys. 3. Z ukształtowania analizowanej funkcji wynika, iż

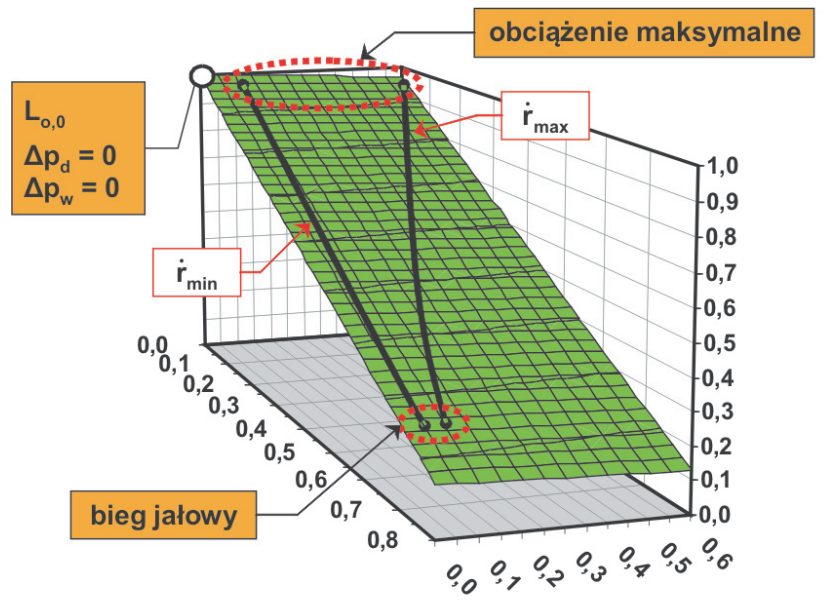

Obieg Seiligera-Sabathe'a $\varepsilon=8,8 ; E=30 ; \Psi=0,9$

$$
L_{o} / L_{o, 0}=f\left(\Delta p_{d} / p_{0} ; \Delta p_{w} / p_{0}\right)
$$

Fig. 3. Relative work of the reference Seiliger-Sabathe cycle depending on the resistance of the inlet and exhaust systems

Rys. 3. Względna praca obiegu porównawczego Seiligera-Sabathe'a w zależności od oporów układu dolotowego i wylotowego 
and the work area of the real engine for its orientation against the plane of the work of the reference cycle;

- the area ,idle" (Fig. 3) is characterized by a large drop in pressure $\Delta p_{d}$ of the fresh charge in the inlet system which is a result of a slight throttle opening in this range of engine operation; at the same time, in the exhaust system we can observe a little drop in pressure $\Delta \mathrm{p}_{\mathrm{w}}$, which is the effect of a lesser stream of the exhaust gases;

- the area „maximum load” (Fig. 3) is characterized by a small drop in pressure $\Delta \mathrm{p}_{\mathrm{d}}$ in the inlet system which is a result of a full throttle opening and a higher pressure $\Delta p_{w}$ drop in the exhaust system, which is the effect of a larger stream of the exhaust gases.

Real engine work area (Fig. 3) is additionally limited by $\dot{\mathrm{r}}_{\text {min }}$ line that characterizes the flow resistance in the charge exchange system for a minimum speed of the tested engine and line $\dot{\mathrm{r}}_{\max }$ representing the pressure drops for the maximum engine speed.

\section{Determining of the average pressure drops in the charge exchange system}

Experimental tests of the flow resistance in the inlet/ exhaust system of a 1170A1.046 spark ignition engine have been carried out. The experiment plan shown on the work area in the configuration:

$$
\dot{\mathrm{i}}-\mathrm{M}_{\mathrm{o}} \text { (engine speed-torque), }
$$

within which the work points of the engine (measuring points) were determined have been shown in Fig. 4.

The quantities characterizing the tested flow resistance in the charge exchange system are the average pressure drops that were determined based on the engine indication. The engine indication enabled the determining of the course of the pressure $\mathrm{p}$ changes inside the cylinder depending on its volume V (Fig. 5) i.e. a function:

$$
\mathrm{p}=\mathrm{f}(\mathrm{V})
$$

The average pressure drop $\Delta \mathrm{p}_{\mathrm{d}}$ during the flow of the fresh charge into the engine was determined as:

$$
\Delta \mathrm{p}_{\mathrm{d}}=\mathrm{p}_{0}-\frac{\int_{\mathrm{V}_{\mathrm{GZP}}}^{\mathrm{V}_{\mathrm{DZP}}} \mathrm{pdV}}{\mathrm{V}_{\mathrm{s}}}
$$

and the average pressure drop $\Delta \mathrm{p}_{\mathrm{w}}$ of the flow of the gases in the exhaust system according to:

$$
\Delta \mathrm{p}_{\mathrm{W}}=\frac{\left|\int_{\mathrm{V}_{\mathrm{DZP}}}^{\mathrm{V}_{\mathrm{GZP}}} \mathrm{pdV}\right|}{\mathrm{V}_{\mathrm{s}}}-\mathrm{p}_{0}
$$

As the above formulas indicate, the individual pressure drops in the charge exchange system were averaged in the extreme piston positions during the exhaust and inlet strokes. spadek ciśnienia $\Delta \mathrm{p}_{\mathrm{d}}$ na dopływie do silnika, podczas zasilania świeżym ładunkiem, znacznie intensywniej oddziałuje na wartość pracy obiegu niż opory $\Delta \mathrm{p}_{\mathrm{w}}$ przepływu spalin przez układ wylotowy.

Względną pracę obiegu porównawczego przedstawiono na rysunku 3 w szerszym zakresie zmian oporów przepływu. Dlatego też zaznaczono na rysunku charakterystyczny punkt pracy obiegu idealnego:

$-\mathbf{L}_{\mathbf{0}, \mathbf{0}}$ - punkt pracy obiegu idealnego dla $\Delta \mathrm{p}_{\mathrm{d}}=0$ oraz $\Delta \mathrm{p}_{\mathrm{w}}=0$, oraz pole pracy silnika rzeczywistego dla jego zorientowania względem płaszczyzny pracy obiegu porównawczego;

- obszar „bieg jałowy” (rys. 3) charakteryzuje się dużym spadkiem ciśnienia $\Delta \mathrm{p}_{\mathrm{d}}$ świeżego ładunku w układzie dolotowym, który jest rezultatem przede wszystkim niewielkiego otwarcia przepustnicy w tym zakresie pracy silnika; jednocześnie w układzie wylotowym obserwuje się niewielki spadek ciśnienia $\Delta \mathrm{p}_{\mathrm{w}}$, co jest efektem małego strumienia spalin;

- obszar „obciążenie maksymalne” (rys. 3) charakteryzuje się małym spadkiem ciśnienia $\Delta \mathrm{p}_{\mathrm{d}}$ w układzie dolotowym, który jest efektem pełnego otwarcia przepustnicy oraz większym spadkiem ciśnienia $\Delta \mathrm{p}_{\mathrm{w}}$ w układzie wylotowym, związanym z dużą wartością strumienia spalin.

Pole pracy silnika rzeczywistego (rys. 3) jest dodatkowo ograniczone linią $\dot{\mathrm{r}}_{\text {min }}$ charakteryzującą opory przepływu w układzie wymiany ładunku dla minimalnej prędkości obrotowej badanego silnika oraz linią $\dot{\mathrm{r}}_{\max }$ reprezentującą spadki ciśnienia dla maksymalnej prędkości obrotowej silnika.

\section{Określenie średnich spadków ciśnienia w ukladzie wymiany ladunku}

Przeprowadzono eksperymentalne badania oporów przepływu w układzie dolotowym i wylotowym silnika o zapłonie iskrowym, typ 1170A1.046. Plan eksperymentu na tle pola pracy silnika w układzie:

$$
\dot{\mathrm{r}}-\mathrm{M}_{\mathrm{o}} \text { (prędkość obrotowa - moment obrotowy), }
$$

w ramach którego określono punkty pracy silnika, w których dokonywano pomiarów, przedstawiono na rys. 4.

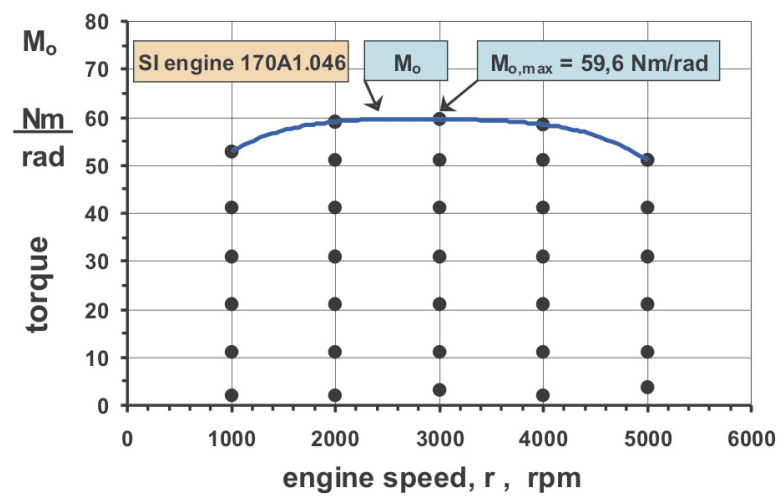

Fig. 4. Experiment plan as shown on the work area $M_{o}=f(\dot{r})$ of the tested spark ignition engine

Rys. 4. Plan eksperymentu na tle pola pracy $M_{o}=f(\dot{\mathrm{r}})$ badanego silnika ZI 


\section{Pressure drop $\Delta p_{d}$ on the inlet side of the engine}

The results of the tests of the pressure drops $\Delta p_{d}$ of the air on the inlet side, depending on the relative load (torque) at steady engine speeds have been shown in Fig. 6. For comparison, the tested pressure drops $\Delta \mathrm{p}_{\mathrm{d}}$ have also been presented as a function of relative effective power in Fig. 7 for $\dot{\mathrm{r}}=\mathrm{idem}$.

Under real engine operating conditions a linear dependence has been observed between the pressure drop in the inlet system and the obtained effective work (Fig. 6 and 7). No significant influence has been observed of the engine speed on the pressure drop $\Delta \mathrm{p}_{\mathrm{d}}$ on the inlet side of the engine in the configuration shown in Fig. 6. Yet, a significant impact on the pressure drop $\Delta \mathrm{p}_{\mathrm{d}}$ has the engine load, which is mainly related to the throttle angle. A maximum closing of the throttle at idle $\left(\mathrm{M}_{\mathrm{o}}=0\right)$ results in the highest pressure drop $\Delta \mathrm{p}_{\mathrm{d}}$. Its value decreases with the increase of the load, which is a result of the gradual throttle opening. The pressure drop $\Delta \mathrm{p}_{\mathrm{d}}$ reaches the lowest values in the external operating characteristics i.e. at maximum load $\left(\mathrm{M}_{\mathrm{o}} / \mathrm{M}_{\mathrm{o}, \mathrm{z}}=1\right)-$ full throttle opening (Fig. 6 and 7).

As mentioned before, Fig. 6, showing the extent of the pressure drop $\Delta \mathrm{p}_{\mathrm{d}}$ on the inlet side of the engine in the function of torque, a significant impact of the engine speed on this pressure drop is not observed. Hence, in this system we can determine one curve of approximation covering the whole work area of the engine:

$$
\left(\frac{\Delta \mathrm{p}_{\mathrm{d}}}{\mathrm{p}_{0}}\right)=\mathrm{f}\left(\frac{\mathrm{M}_{\mathrm{o}}}{\mathrm{M}_{\mathrm{o}, \max }}\right)
$$

where $\left(\mathrm{M}_{\mathrm{o}} / \mathrm{M}_{\mathrm{o} \text { max }}\right)$ denotes relative torque compared to the maximum engine torque $\mathrm{M}_{\mathrm{o} \text {,max }}$ (Fig. 4).

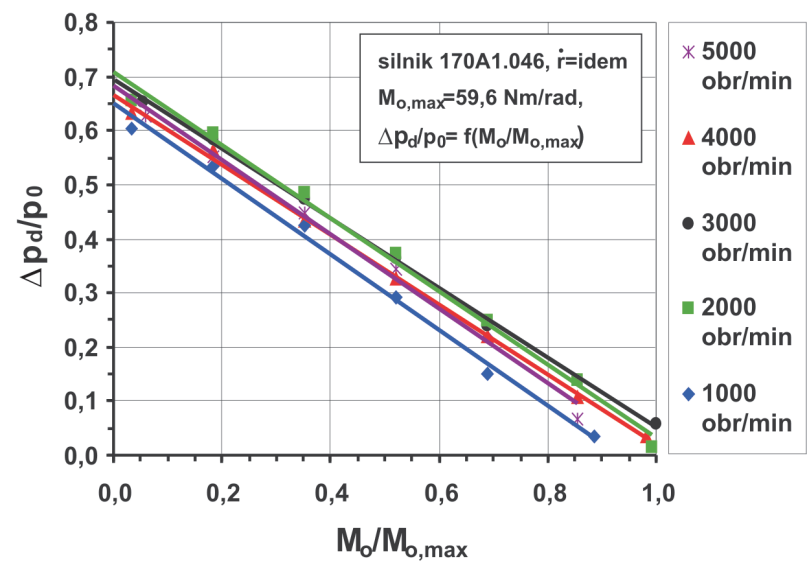

Fig. 6. Average pressure drop $\Delta p_{d}$ on the inlet side of the engine depending on the relative torque $\mathrm{M}_{\mathrm{o}} / \mathrm{M}_{\mathrm{o} \text { max }}$

Rys. 6. Średni spadek ciśnienia $\triangle p_{d}$ po stronie doplywu świeżego ładunku do silnika w zależności od względnego momentu obrotowego $M_{o} / M_{o, \max }$

The work of the reference Seiliger-Sabathe cycle is a linear function (15) and (19) of the resistance of the inlet system (Fig. 3), which indicates that the curve of approximation (23) should be a first order polynomial. The coefficients
Wielkościami charakteryzującymi badane opory przepływu w układzie wymiany ładunku są odpowiednie, średnie spadki ciśnienia, które wyznaczano na podstawie badań indykacyjnych silnika. Badania indykacyjne umożliwiają wyznaczenie przebiegu zmian ciśnienia $\mathrm{p}$ wewnątrz cylindra w zależności od jego objętości V (rys. 5), czyli funkcji o postaci (20).

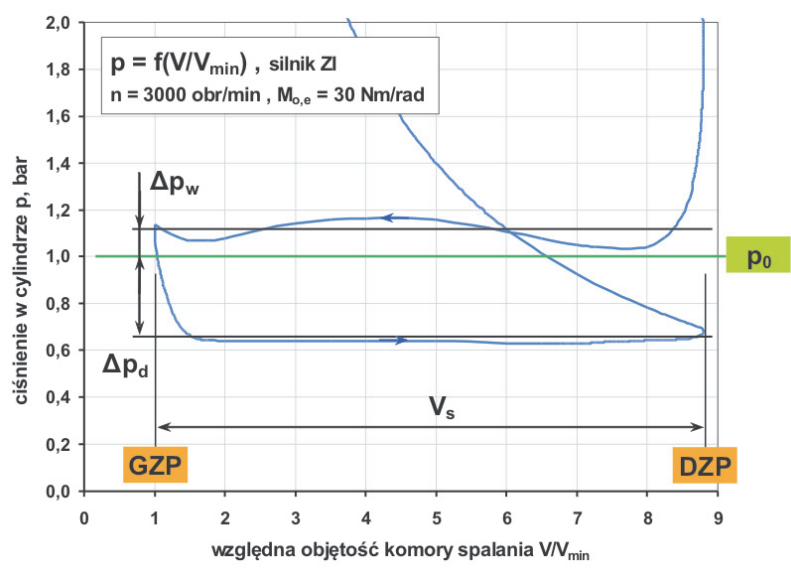

Fig. 5. The schematics of the average pressure drops in the charge exchange system

Rys. 5. Schemat wyznaczania średnich spadków ciśnienia w układzie wymiany tadunku

Średni spadek ciśnienia $\Delta \mathrm{p}_{\mathrm{d}}$ podczas przepływu świeżego ładunku do silnika wyznaczano jako (21), natomiast średni spadek ciśnienia $\Delta \mathrm{p}_{\mathrm{w}}$ przepływu spalin w układzie wylotowym - wg schematu (22).

Jak wskazują powyższe formuły, odpowiednie spadki ciśnienia w układzie wymiany ładunku uśredniano w zakresie skrajnych położeń tłoka w czasie suwu wypływu spalin i dopływu świeżego ładunku.

\section{Spadek ciśnienia $\Delta \mathrm{p}_{\mathrm{d}}$ po stronie dopływu świeżego ladunku do silnika}

Wyniki badań spadków ciśnień $\Delta \mathrm{p}_{\mathrm{d}}$ powietrza po stronie napływowej, w zależności od obciążenia (momentu obrotowego) względnego, przy ustalonych prędkościach obrotowych silnika, przedstawiono na rys. 6. Dla porównania, badane spadki ciśnień $\Delta \mathrm{p}_{\mathrm{d}}$ przedstawiono także w funkcji względnej mocy efektywnej, na rys. 7 dla $\dot{r}=$ idem.

W warunkach pracy silnika rzeczywistego także stwierdzono liniową współzależność spadku ciśnienia powietrza w układzie dolotowym i uzyskiwanej pracy efektywnej (rys. 6 i 7). Nie obserwuje się istotnego wpływu prędkości obrotowej silnika na wielkość spadku ciśnienia $\Delta \mathrm{p}_{\mathrm{d}}$ po stronie napływu świeżego ładunku, w układzie przedstawionym na rys. 6 . Znaczący wpływ na wartość spadku ciśnienia $\Delta \mathrm{p}_{\mathrm{d}}$ ma natomiast obciążenie silnika, co związane jest głównie z kątem otwarcia przepustnicy. Maksymalne przymknięcie przepustnicy na biegu jałowym $\left(\mathrm{M}_{\mathrm{o}}=0\right)$ skutkuje największą wartością spadku ciśnienia $\Delta \mathrm{p}_{\mathrm{d}}$. Jego wartość maleje ze wzrostem obciążenia, co jest rezultatem stopniowego otwierania przepustnicy. Spadek ciśnienia $\Delta \mathrm{p}_{\mathrm{d}}$ osiąga wartości najniższe 
of the linear equation approximating the measurement data have been determined by the least squares method [6] and the following has been obtained:

$$
\left(\frac{\Delta \mathrm{p}_{\mathrm{d}}}{\mathrm{p}_{0}}\right)=-0,6592\left(\frac{\mathrm{M}_{\mathrm{o}}}{\mathrm{M}_{\mathrm{o}, \max }}\right)+0,6770
$$

at the correlation coefficient:

$$
\mathrm{R}^{2}=0.980
$$

That has been graphically shown in Fig. 8. This figure, apart from the line approximating the tests results, shows the dependence of the flow resistance $\Delta \mathrm{p}_{\mathrm{d}}$ of the fresh charge in the inlet system on the work of the theoretical and reference Seiliger-Sabathe cycle. The aim of this comparison is to emphasize the full qualitative (linear) accordance of the dependence of the load on the inlet system flow resistance for both the real engine cycle and the reference one.

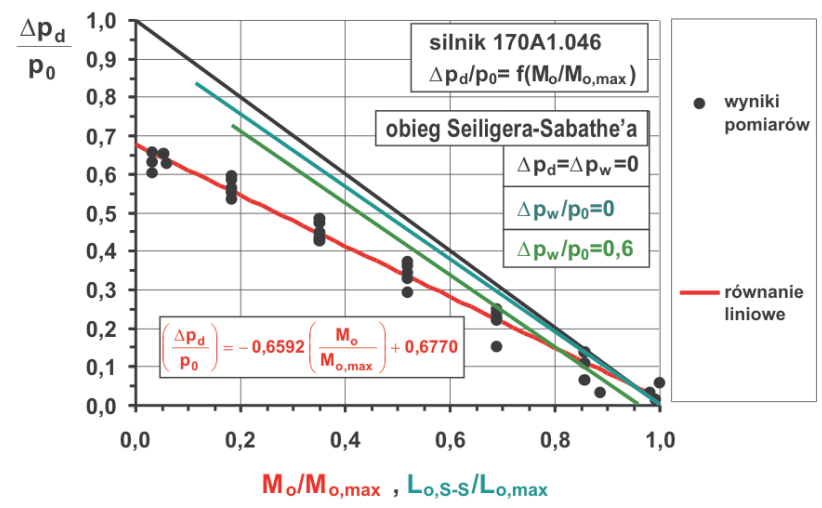

Fig. 8. Average pressure drop $\Delta \mathrm{p}_{\mathrm{d}}$ on the inlet side of the engine depending on the relative engine load for a real engine cycle and the theoretical and reference Seiliger-Sabathe engine cycle

Rys. 8. Średni spadek ciśnienia $\Delta p_{d}$ po stronie dopływu świeżego ładunku do silnika $w$ zależności od obciążenia względnego dla rzeczywistego obiegu silnika oraz teoretycznego i porównawczego obiegu Seiligera-Sabathe'a

\section{Pressure drop $\Delta p_{w}$ of the gases in the engine exhaust system}

The test results of the pressure drops $\Delta \mathrm{p}_{\mathrm{w}}$ of the gases in the engine exhaust system depending on the relative torque at steady engine speeds have been shown in Fig. 9. For comparison, the tested pressure drops have also been presented in the function of relative effective power (Fig. 10), also for $\dot{r}=i d e m$.

The codependence of the flow resistance in the exhaust system and the obtained effective work varies from the respective codependence in the inlet system. The average pressure drop $\Delta \mathrm{p}_{\mathrm{w}}$ on the exhaust side grows with the increase of the load and engine speed (Fig. 9). Such a phenomenon is the result of the increase of the gas stream and the speed of the gases.

In Figures 6 and 8, showing the value of the pressure drop $\Delta \mathrm{p}_{\mathrm{d}}$ on the inlet side of the engine in the function of relative torque we do not observe a significant influence of na charakterystyce eksploatacyjnej, zewnętrznej, tzn. przy maksymalnym obciążeniu $\left(\mathrm{M}_{\mathrm{o}} / \mathrm{M}_{\mathrm{o}, \mathrm{z}}=1\right)$ - pełnym otwarciu przepustnicy (rys. 6 i 7).

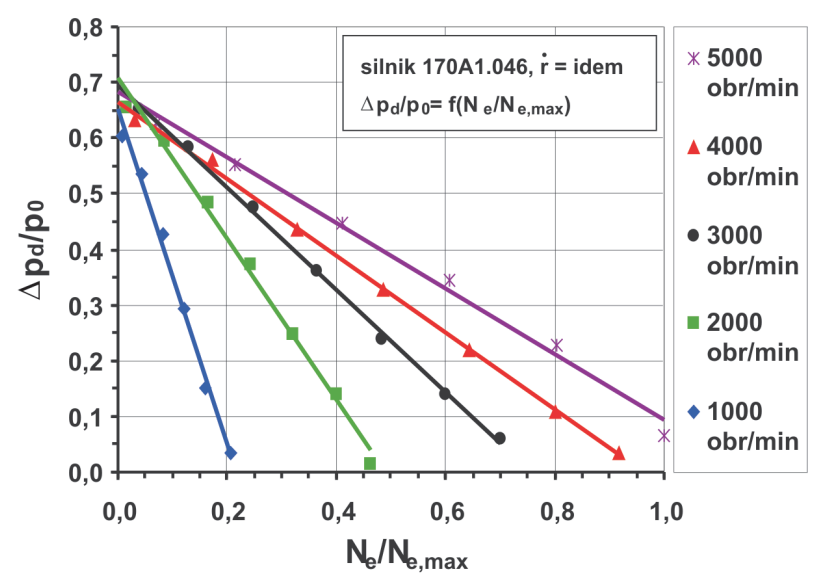

Fig. 7. Average pressure drop $\Delta \mathrm{p}_{\mathrm{d}}$ on the inlet side of the engine depending on the relative effective power $\mathrm{N}_{\mathrm{e}} / \mathrm{N}_{\mathrm{e}, \text { max }}$

Rys. 7. Średni spadek ciśnienia $\Delta p_{d}$ po stronie dopływu świeżego ładunku do silnika w zależności od względnej mocy efektywnej $N_{e} / N_{e, m a x}$

Jak wspomniano, na rysunku 6, przedstawiającym wielkość spadku ciśnienia $\Delta \mathrm{p}_{\mathrm{d}}$ po stronie napływu świeżego ładunku w funkcji momentu obrotowego, nie obserwuje się znaczącego wpływu prędkości obrotowej na ten spadek ciśnienia. Zatem w tym układzie można wyznaczyć jedną krzywą aproksymacji, obejmującą całe pole pracy silnika (23), gdzie $\left(\mathrm{M}_{\mathrm{o}} / \mathrm{M}_{\mathrm{o} \text { max }}\right)$ oznacza względny moment obrotowy, odniesiony do maksymalnego momentu obrotowego $\mathrm{M}_{\text {o,max }}$ silnika (rys. 4).

Praca obiegu porównawczego Seiligera-Sabathe'a jest liniową funkcją (15) i (19) oporów układu dolotowego (rys. 3), co wskazuje, iż krzywą aproksymacji (23) powinien być wielomian pierwszego stopnia. Współczynniki liniowego równania aproksymującego dane pomiarowe wyznaczono metodą najmniejszych kwadratów [6] i uzyskano jego postać (24), przy współczynniku korelacji (25), którą przedstawiono graficznie na rys. 8. Na rysunku tym oprócz linii aproksymującej wyniki badań eksperymentalnych dodatkowo, dla porównania, przedstawiono zależność wpływu oporów $\Delta \mathrm{p}_{\mathrm{d}}$ przepływu świeżego ładunku przez układ dolotowy na pracę teoretycznego i porównawczego obiegu Seiligera-Sabathe'a. Celem tego porównania jest podkreślenie pełnej jakościowej (liniowej) zgodności zależności obciążenia od oporów układu dolotowego zarówno dla rzeczywistego obiegu silnika, jak i obiegu porównawczego.

\section{Spadek ciśnienia $\Delta \mathbf{p}_{\mathrm{w}}$ spalin $\mathbf{w}$ układzie wylotowym silnika}

Wyniki badań spadków ciśnień $\Delta \mathrm{p}_{\mathrm{w}}$ spalin w układzie wylotowym silnika, w zależności od względnego momentu obrotowego, przy ustalonych prędkościach obrotowych silnika, przedstawiono na rys. 9. Dla porównania, badane spadki ciśnień przedstawiono także w funkcji względnej mocy efektywnej (rys. 10), także dla $\dot{\mathrm{r}}=$ idem. 
the engine speed on this pressure drop. However, the smallest influence of the engine speed on the average pressure drop $\Delta \mathrm{p}_{\mathrm{w}}$ of the gases on the exhaust side is observed when this pressure drop is presented as a dependence on the relative effective power (Fig. 10).

Hence, for this system a single approximation curve has been determined for the whole work area as shown in Fig. 11. In this case the table differences also showed that the most appropriate approximating curve is the second order polynomial:

$$
\left(\frac{\Delta p_{w}}{p_{0}}\right)=A\left(\frac{N_{e}}{N_{e, \max }}\right)^{2}+B\left(\frac{N_{e}}{N_{e, \max }}\right)+C
$$

where: $\mathrm{N}_{\mathrm{e}, \max }-$ maximum effective engine power, $\mathrm{A}, \mathrm{B}, \mathrm{C}-$ approximating equation coefficient.

The coefficients A, B and C of equation (26) have been obtained through the least squares method [6], thus obtaining (26) as below:

$$
\frac{\Delta \mathrm{p}_{\mathrm{w}}}{\mathrm{p}_{0}}=0.4861\left(\frac{\mathrm{N}_{\mathrm{e}}}{\mathrm{N}_{\mathrm{e}, \max }}\right)^{2}+0.0539\left(\frac{\mathrm{N}_{\mathrm{e}}}{\mathrm{N}_{\mathrm{e}, \text { max }}}\right)+0.0475
$$

at the correlation coefficient:

$$
\mathrm{R}_{2}=0.9779
$$

Considering the relation:

$$
\mathrm{N}_{\mathrm{e}}=2 \pi \dot{\mathrm{r}} \mathrm{M}_{\mathrm{o}}
$$

in equations (26) and (27) the relative pressure drop $\left(\Delta \mathrm{p}_{\mathrm{w}} / \mathrm{p}_{0}\right)$ of the gases on the exhaust side of the engine we can express depending on the engine relative torque $\left(\mathrm{M}_{\mathrm{o}} \mathrm{M}_{\mathrm{o}, \max }\right)$ and its speed $\dot{\mathrm{r}}$ :

$$
\begin{aligned}
\left(\frac{\Delta \mathrm{p}_{\mathrm{w}}}{\mathrm{p}_{0}}\right)= & \mathrm{A}(2 \pi \dot{\mathrm{r}})^{2}\left(\frac{\mathrm{M}_{\mathrm{o}, \max }}{\mathrm{N}_{\mathrm{e}, \text { max }}}\right)^{2}\left(\frac{\mathrm{M}_{o}}{\mathrm{M}_{\mathrm{o}, \text { max }}}\right)^{2}+ \\
& +\mathrm{B} 2 \pi \dot{\mathrm{r}}\left(\frac{\mathrm{M}_{\mathrm{o}, \max }}{\mathrm{N}_{\mathrm{e}, \text { max }}}\right)\left(\frac{\mathrm{M}_{\mathrm{o}}}{\mathrm{M}_{\mathrm{o}, \text { max }}}\right)+\mathrm{C}
\end{aligned}
$$

or, including the coefficients $\mathrm{A}, \mathrm{B}$ and $\mathrm{C}$, the multinomial (30) as below:

$$
\begin{aligned}
\left(\frac{\Delta \mathrm{p}_{\mathrm{w}}}{\mathrm{p}_{0}}\right)= & 0.4861(2 \pi \dot{\mathrm{r}})^{2}\left(\frac{\mathrm{M}_{\mathrm{o}, \max }}{\mathrm{N}_{\mathrm{e}, \text { max }}}\right)^{2}\left(\frac{\mathrm{M}_{\mathrm{o}}}{\mathrm{M}_{\mathrm{o}, \max }}\right)^{2}+ \\
& +0.0539(2 \pi \dot{\mathrm{r}})\left(\frac{\mathrm{M}_{\mathrm{o}, \max }}{\mathrm{N}_{\mathrm{e}, \text { max }}}\right)\left(\frac{\mathrm{M}_{\mathrm{o}}}{\mathrm{M}_{\mathrm{o}, \max }}\right)+0.0475
\end{aligned}
$$

Equation (31), expressing the flow resistance of the gases in the exhaust system, in the full work area of the engine (in a spatial system) has been shown in Fig. 12.

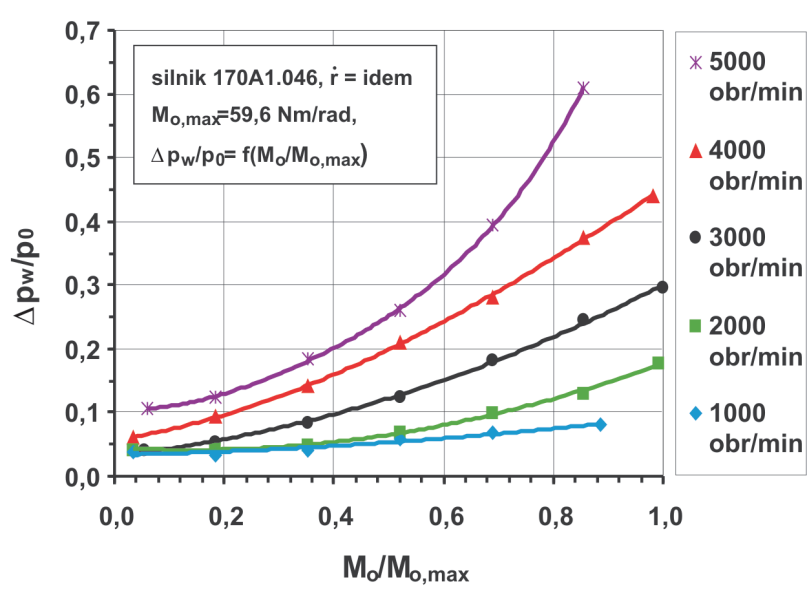

Fig. 9. Average pressure drop $\Delta \mathrm{p}_{\mathrm{w}}$ of the gases in the engine exhaust system depending on the relative torque $\mathrm{M}_{\mathrm{o}} / \mathrm{M}_{\mathrm{o} \text {,max }}$

Rys. 9. Sredni spadek ciśnienia $\Delta p_{\text {w }}$ spalin $w$ ukladzie wylotowym silnika w zależności od względnego momentu obrotowego $M_{o} / M_{o, \max }$

Współzależność oporów w układzie wylotowym i uzyskiwanej pracy efektywnej kształtuje się odmiennie aniżeli odpowiednia współzależność w układzie dolotowym. Średni spadek ciśnienia $\Delta \mathrm{p}_{\mathrm{w}}$ po stronie wypływu spalin z silnika rośnie zarówno ze wzrostem obciążenia, jak i prędkości obrotowej silnika (rys. 9). Sytuacja taka jest rezultatem wzrostu strumienia i prędkości wypływających spalin.

Na rysunkach 6 i 8, przedstawiających wielkość spad$\mathrm{ku}$ ciśnienia $\Delta \mathrm{p}_{\mathrm{d}}$ po stronie napływu świeżego ładunku w funkcji względnego momentu obrotowego, nie obserwuje się znaczącego wpływu prędkości obrotowej na ten spadek ciśnienia. Z kolei najmniejszy wpływ prędkości obrotowej na średni spadek ciśnienia $\Delta \mathrm{p}_{\mathrm{w}}$ spalin po stronie wypływowej z silnika obserwuje się, gdy ten spadek ciśnienia przedstawi się w zależności od względnej mocy efektywnej (rys. 10).

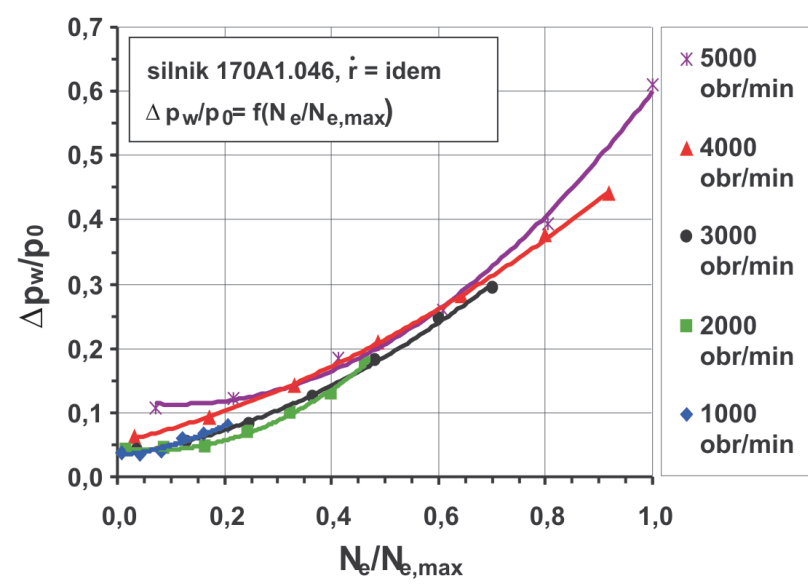

Fig. 10. Average pressure drop $\Delta \mathrm{p}_{\mathrm{w}}$ of the gases in the engine exhaust system depending on the relative effective power $\mathrm{N}_{\mathrm{e}} / \mathrm{N}_{\mathrm{e}, \max }$

Rys. 10. Średni spadek ciśnienia $\Delta p_{w}$ spalin w układzie wylotowym silnika w zależności od względnej mocy efektywnej $N_{e} / N_{e, \max }$ 


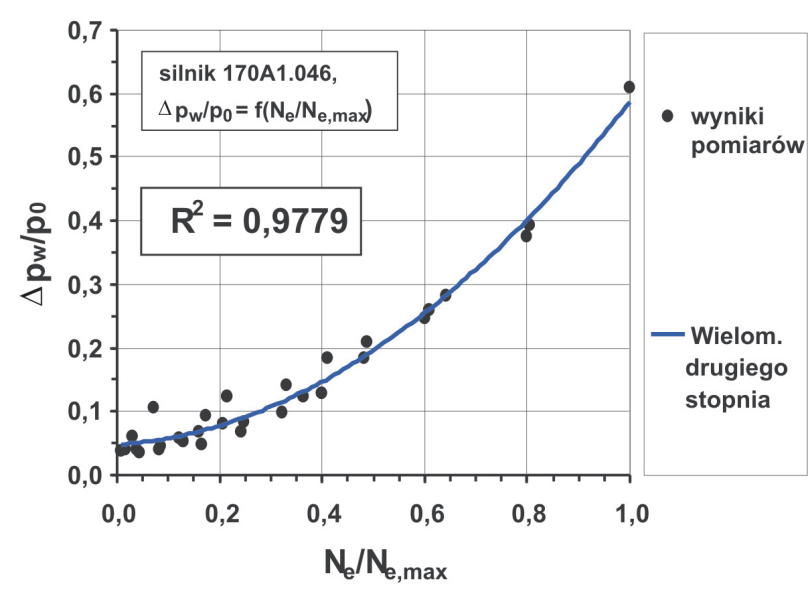

Fig. 11. Average pressure drop $\Delta \mathrm{p}_{\mathrm{w}}$ of the gases in the engine exhaust system; approximation by a second order polynomial

Rys. 11. Średni spadek ciśnienia $\Delta p_{w}$ spalin w układzie wylotowym silnika; aproksymacja wielomianem drugiego stopnia

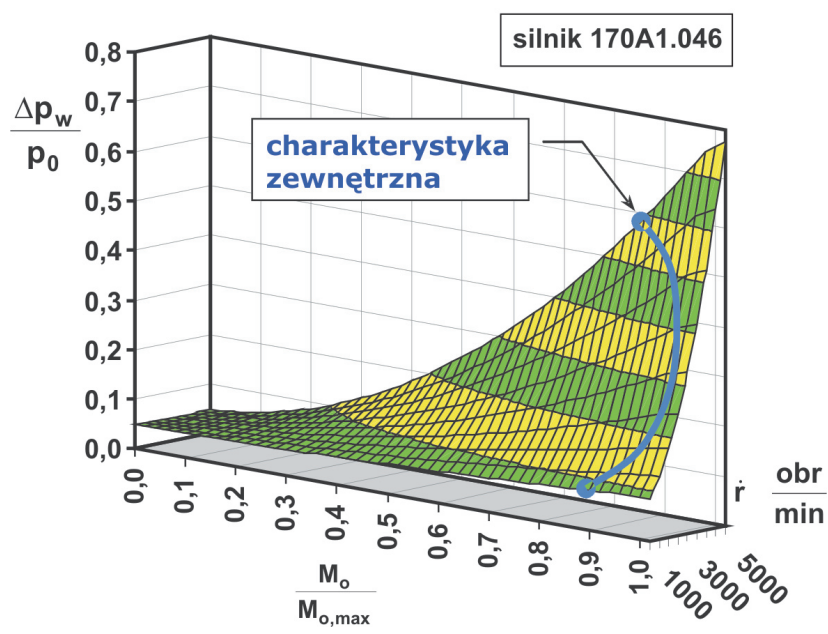

Fig. 12. Average pressure drop $\Delta \mathrm{p}_{\mathrm{w}}$ of the gases in the engine exhaust system in the full area of engine work; surface approximation (31)

Rys. 12. Średni spadek ciśnienia $\Delta p_{\text {w }}$ spalin w układzie wylotowym w całym polu pracy silnika; aproksymacja powierzchnia - wzór (31)

\section{Conclusions}

As far as the charge exchange system in a combustion engine is concerned significant are the positive (resulting from its function) and the negative - energy related (economical) aspects of installing its main components. The energy related aspect manifests as a growth of the flow resistance in the charge exchange system. It should be noted that the growth of the flow resistance of both the fresh charge and the gases in the exhaust system leads to a growth in the work of the charge exchange, thus, contributing to the decrease in the internal and effective work (this leads to a drop in the engine efficiency at part loads in particular).

The codependence of the flow resistance in the inlet manifold and the engine load is close to linear, hence, this resistance is a qualitative element of the engine power control. The characteristic feature of this type of power control is maintaining the air excess ratio $\lambda$ and the stoichiometric mixture ready for combustion on an almost unchanged level
Zatem dla tego układu wyznaczono jedną krzywą aproksymacji dla całego pola pracy, którą przedstawiono na rys. 11 . W tym przypadku zestawienie różnic tablicowych również wykazało, że najbardziej odpowiednią krzywą aproksymującą jest wielomian drugiego stopnia (26),

gdzie: $\mathrm{N}_{\text {e.max }}$ - maksymalna moc efektywna silnika, A, B, $\mathrm{C}$ - współczynniki równania aproksymacyjnego.

Współczynniki A, B i C równania (26) wyznaczono metodą najmniejszych kwadratów [6], uzyskując (26) w postaci (27), przy współczynniku korelacji (28).

Uwzględniając w równaniach (26) i (27) związek (29), względny spadek ciśnienia $\left(\Delta \mathrm{p}_{\mathrm{w}} / \mathrm{p}_{0}\right)$ spalin w układzie wylotowym można wyrazić, w zależności od względnego momentu obrotowego $\left(\mathrm{M}_{\mathrm{o}} / \mathrm{M}_{\mathrm{o}, \max }\right)$ silnika i jego prędkości obrotowej r przez (30) lub, po uwzględnieniu wartości współczynników A, B i C, wielomianu (30) w postaci (31).

Równanie (31), wyrażające opory przepływu spalin w układzie wylotowym, w pełnym polu pracy silnika (w układzie przestrzennym) przedstawiono na rys. 12 .

\section{Podsumowanie i wnioski}

W odniesieniu do układu wymiany ładunku silnika spalinowego istotne są pozytywne (wynikające z funkcji) oraz negatywne, energetyczne (ekonomiczne) aspekty instalowania głównych jego elementów. Aspekt energetyczny przejawia się jako wzrost oporów przepływu w układzie wymiany ładunku. Należy mieć na uwadze, iż zwiększenie zarówno oporu przepływu świeżego ładunku, jak i spalin powoduje wzrost pracy wymiany ładunku, jednocześnie przyczyniając się do zmniejszenia pracy wewnętrznej i efektywnej (sytuacja taka prowadzi także do spadku sprawności efektywnej silnika, szczególnie w zakresie obciążeń częściowych).

Wzajemna zależność oporów przepływu układu dolotowego i obciążenia jest zbliżona do liniowej, zatem opór ten nadaje się na element ilościowej regulacji osiąganej przez silnik mocy. Cechą charakterystyczną tego typu regulacji jest utrzymanie nadmiaru tlenu (powietrza) $\lambda$ oraz składu stechiometrycznego mieszanki palnej przygotowanej do procesu spalania prawie na niezmienionym poziomie, niezależnie od samego obciążenia silnika. Odpowiednie dopasowanie masy czynnika roboczego, do pozyskiwanej pracy efektywnej, osiąga się najczęściej dzięki odpowiedniemu ustawieniu przepustnicy (dławienie) na kanale dopływowym. Jednakże stosowanie tradycyjnej regulacji ilościowej jest niekorzystne, szczególnie z termodynamicznego punktu widzenia. Podczas przepływu powietrza przez przepustnicę występuje intensywne dławienie płynu (izentalpowe), które jako przemiana zawsze nieodwracalna generuje straty egzergii (wzrost wykonanej pracy wymiany ładunku) w procesie napełniania silnika. Znaczne zmniejszenie pracy wymiany ładunku, a tym samym wzrost sprawności energetycznej silnika spalinowego można osiągnąć przez wprowadzenie zmian w układach regulacji i sterowania (zastosowanie systemów niezależnego sterowania zaworami).

W polu pracy silnika spalinowego istnieje odmienność kształtowania się oporów na dopływie i wypływie, aczkolwiek istotne jest ich łączne oddziaływanie na pracę silnika spalinowego. Opory przepływu w układzie dolotowym 
irrespective of the engine load. An appropriate match of the mass of the medium with the obtained effective work is most often achieved through an appropriate throttle position (choking) in the inlet duct. Yet, the application of traditional qualitative control is disadvantageous, particularly in the thermodynamic aspect. When the air passes through the throttle, isenthalpic choking of the fluid occurs which, as an irreversible change, generates losses of exergy (increase in the work of the charge exchange) in the cylinder filling process. A significant reduction of the work of the charge exchange, thus an increase in the engine efficiency, can be achieved through modifications in the power control systems (the application of a system of independent valve control).

In the work area of a combustion engine the flow resistance varies at the inlet and exhaust side of the engine, however, their joint influence on the engine operation is important. The flow resistance in the inlet system more intensely influences the engine cycle than it is in the case of the exhaust system.

An important issue related to the flow resistance in the charge exchange system is the mutual dependence of the flow resistance of the fresh charge in the inlet system and the flow resistance of the gases in the exhaust system. The results of relevant research and analyses of the problem shall be discussed in further publications.

\section{Bibliography/Literatura}

[1] Postrzednik S., Żmudka Z.: Termodynamiczne oraz ekologiczne uwarunkowania eksploatacji łłokowych silników spalinowych, Wydawnictwo Politechniki Śląskiej, Gliwice 2007.

[2] Postrzednik S.: Termodynamika zjawisk przepływowych, Wydawnictwo Politechniki Śląskiej, Gliwice 2006.

[3] Szargut J.: Termodynamika techniczna, Wydawnictwo Politechniki Śląskiej, Gliwice 2000.

[4] Postrzednik S., Żmudka Z. i in.: Ekologiczne oraz eksploatacyjne uwarunkowania współpracy konwertorów katalitycznych z tłokowymi silnikami spalinowymi. Projekt badawczy numer 5T12D 031 24. PBU-14/RIE-6/03. 27.03.2003 - 26.07.2005. Sprawozdanie, Gliwice 2005.

[5] Żmudka Z., Postrzednik S.: Opór przepływu w układzie dolotowym jako element regulacji obciążenia silnika spalinowego. Czasopismo Techniczne, zeszyt 11/2008 (105). Mechanika z. 7-M/2008. Wydawnictwo Politechniki Krakowskiej, Kraków 2008.

[6] Żmudka Z., Postrzednik S.: Zastosowanie rachunku wyrównawczego do wyznaczania parametrów obiegu porównawczego silnika spalinowego. Termodynamika w nauce i gospodarce, tom II, praca zbiorowa pod red. Zbigniewa Gnutka i Władysława Gajewskiego. Oficyna Wydawnicza Politechniki Wrocławskiej, Wrocław 2008.

[7] Żmudka Z., Postrzednik S.: Opory przepływu w obrębie wybranych elementów układu wylotowego silnika spalinowego. Termodynamika w nauce i gospodarce, tom II, praca zbiorowa pod red. Zbigniewa Gnutka i Władysława Gajewskiego. Oficyna Wydawnicza Politechniki Wrocławskiej, Wrocław 2008. znacznie intensywniej oddziałują na wartość pracy obiegu (silnika) niż opory przepływu spalin przez układ wylotowy.

Istotnym zagadnieniem związanym z oporami w układzie wymiany ładunku jest kształtowanie się wzajemnej współzależności oporów przepływu świeżego ładunku w układzie dolotowym oraz oporów przepływu spalin w układzie wylotowym. Wyniki badań i analiza tego problemu będą omówione w kolejnych publikacjach.

Artykut recenzowany

\section{Nomenclature/Skróty i oznaczenia}

BDC bottom dead center/DZP - dolny zwrotny punkt

E energetic-stoichiometric parameter/parametr energetyczno-stechiometryczny

TDC top dead center/GZP - górny zwrotny punkt

$\mathrm{L}_{\mathrm{o}} \quad$ work in the cycle/praca obiegu, J

$\mathrm{L}_{\mathrm{w}} \quad$ charge exchange work/praca wymiany tadunku, $\mathrm{J}$

$\mathrm{M}_{\mathrm{o}}^{\mathrm{w}} \quad$ torque/moment obrotowy, $\mathrm{N} \cdot \mathrm{m} / \mathrm{rad}$

$\mathrm{N}_{\mathrm{e}} \quad$ effective power/moc efektywna, $\mathrm{kW}$

$\mathrm{p} \quad$ pressure/ciśnienie, $\mathrm{Pa}$

$\Delta \mathrm{p}_{\mathrm{d}} \quad$ average pressure drop on the inlet side of the engine/średni spadek ciśnienia po stronie dopływu ładunku do silnika, $\mathrm{Pa}$

$\Delta \mathrm{p}_{\mathrm{w}} \quad$ average pressure drop of the gases in the engine exhaust system/średni spadek ciśnienia po stronie wypływu spalin $z$ silnika, $\mathrm{Pa}$

$\mathrm{Q}_{\mathrm{d}} \quad$ amount of heat supplied to the cycle/ilość ciepla dostarczonego do obiegu, J

$\mathrm{Q}_{\mathrm{w}} \quad$ amount of heat transferred from the cycle/ilość ciepta wyprowadzonego z obiegu, J

engine speed, rpm/prędkość obrotowa, obr/s

temperature/temperatura, $\mathrm{K}$

volume/objętość, $\mathrm{m}^{3}$

spark ignition/ZI - zapłon iskrowy

compression ignition/ZS - zaplon samoczynny

angular speed/prędkość kątowa, rad/s

load parameter(level)/parametr (stopień) obciązenia

compression ratio/stopień sprężania

second distribution number/parametr (stopień) dociązenia heat distribution number/liczba rozdziału ciepta

Mr. Zbigniew Żmudka, DEng. - Senior Lecturer in the Faculty of Environmental Engineering and Energy at Silesian University of Technology in Gliwice.

Dr inż. Zbigniew Żmudka - starszy wykladowca na Wydziale Inżynierii Środowiska i Energetyki Politechniki Śląskiej w Gliwicach.

e-mail: zbigniew.zmudka@polsl.pl

Prof. Stefan Postrzednik, DSc., DEng. - Professor in the Faculty of Environmental Engineering and Energy, Silesian University of Technology in Gliwice.

Prof. dr hab. inż. Stefan Postrzednik - profesor na Wydziale Inżynierii Środowiska i Energetyki Politechniki Śląskiej w Gliwicach.

e-mail: stefan.postrzednik@polsl.pl 